\title{
Compensatory growth of Malaysian prawns reared at high densities during the nursery phase ${ }^{1}$
}

\author{
Helcio Luis de Almeida Marques², Julio Vicente Lombardi²
}

\footnotetext{
1 Pesquisa parcialmente financiada pela Fundação de Amparo à Pesquisa do Estado de São Paulo - FAPESP (Pr. 03/07983-3)

${ }^{2}$ Centro de Pesquisas em Aquicultura - Instituto de Pesca - APTA - Secretaria de Agricultura e Abastecimento (SP).
}

ABSTRACT - The objective of this work was to verify the occurrence of compensatory growth in Malaysian prawn (Macrobrachium rosenbergii) reared in pens, after being stocked in cages under high densities during nursery phase. The experiment was carried out in $0.5 \mathrm{~m}^{2}$ cages and $2-\mathrm{m}^{2}$ pens set in natural bottom pond with $2,400 \mathrm{~m}^{2}$. Prawn post-larvae (PL) with an average weight of $0.026 \pm 0.012 \mathrm{~g}$ (nursery phase) were initially stocked in 16 cages at the densities of 50, 400, 800 and $1,200 \mathrm{PL} \mathrm{m}^{-2}$. Sixty days later, prawns were transferred to 16 growing pens, at the density of $12 \mathrm{prawns}^{-2}$. Initial average weight of the prawn in this phase was the final average weight registered in the nursery phase, as follows: $50 \mathrm{PL} \mathrm{m}{ }^{-2}=2.3 \pm 0.3 \mathrm{~g} ; 400 \mathrm{PL} \mathrm{m}^{-2}=0.5 \pm 0.03 \mathrm{~g} ; 800 \mathrm{PL} \mathrm{m}^{-2}=0.3 \pm 0.05 \mathrm{~g}$ and $1,200 \mathrm{PL} \mathrm{m}^{-2}=0.1 \pm 0.01 \mathrm{~g}$. Commercial rations for prawns (35\% crude protein) were given once a day, in the afternoon. After 244 days, survival, average weight and biomass did not differ significantly among prawns with different initial average weight. Relative growth rate was significantly greater in prawns previously stocked at $1,200 \mathrm{PL} \mathrm{m} \mathrm{m}^{-2}$ and feed conversion efficiency was significantly better for those previously stocked at 400 and 1,200 $\mathrm{PL} \mathrm{m} \mathrm{m}^{-2}$. These results suggest the existence of partial compensatory growth in $M$. rosenbergii, what can successfully carry on stocking of prawns of this species at high densities in the nursery phase.

Key Words: biomass, freshwater prawn, growing, Macrobrachium rosenbergii, pens, survival

\section{Crescimento compensatório em camarões-da-malásia cultivados sob altas densidades durante a fase de berçário}

\begin{abstract}
RESUMO - Este trabalho foi realizado com o objetivo de verificar a ocorrência de crescimento compensatório em camarões-da-malásia (Macrobrachium rosenbergii) cultivados em cercados, após serem estocados em gaiolas sob altas densidades durante a fase de berçário. O experimento foi conduzido em gaiolas com $0,5 \mathrm{~m}^{2}$ e cercados com $2 \mathrm{~m}^{2}$ instalados em um viveiro de fundo natural com $2.400 \mathrm{~m}^{2}$. Pós-larvas (PL) de camarões com peso médio de 0,026 $\pm 0,012 \mathrm{~g}$ (fase de berçário) foram inicialmente estocadas em 16 gaiolas, nas densidades de 50, 400, 800 e 1.200 camarões m². Após 60 dias, os camarões foram transferidos para 16 cercados de engorda, na densidade de 12 camarões $\mathrm{m}^{-2}$. O peso médio inicial dos camarões nessa fase foi o peso médio final registrado na fase de berçário, como segue: $50 \mathrm{PL} \mathrm{m}{ }^{-2}=2,3 \pm 0,3 \mathrm{~g} ; 400 \mathrm{PL} \mathrm{m} \mathrm{m}^{-2}=0,5 \pm 0,03 \mathrm{~g}$; $800 \mathrm{PL} \mathrm{m} \mathrm{m}^{-2}=0,3 \pm 0,05 \mathrm{~g}$ e $1.200 \mathrm{PL} \mathrm{m}^{-2}=0,1 \pm 0,01 \mathrm{~g}$. Ração comercial para camarões (35\% de proteína) foi fornecida uma vez por dia, ao entardecer. Após 244 dias, a sobrevivência, o peso médio e a biomassa não diferiram significativamente entre as densidades de cultivo. A taxa de crescimento relativo foi significativamente maior nos camarões previamente estocados a $1.200 \mathrm{PL} \mathrm{m}{ }^{-2}$ e a eficiência da conversão alimentar, significativamente melhor para aqueles previamente estocados a 400 e $1.200 \mathrm{PL} \mathrm{m}^{-2}$. Esses resultados sugerem a existência de crescimento compensatório parcial em M. rosenbergii, o que pode viabilizar a estocagem de camarões dessa espécie em altas densidades na fase de berçário.
\end{abstract}

Palavras-chave: biomassa, camarões-d’água-doce, cercados, engorda, Macrobrachium rosenbergii, sobrevivência

\section{Introduction}

Global production of Macrobrachium rosenbergii in prawn farming has greatly expanded in the present decade, surpassing 400,000 ton in 2007 (FAO, 2009). However, this increasing interest in freshwater prawn farming must include the development of appropriate culture practices that will reduce costs or increase production. The use of cages for nursing freshwater prawns before transferring them to grow-out ponds may be a viable alternative to replace the use of nursery earthen ponds, due to the practicality of management and mainly to lower costs. This practice was successfully tested by Marques et al. (2000), who reported good survival rates, although the mean final weight had been greatly reduced when nursing was performed at high densities. 
Compensatory growth has been referred by many authors as a phase of rapid growth when favorable conditions are restored following a period of growth depression, occasioned by suboptimal conditions just as feed deprivation (Turano et al., 2007), low temperature (Nicieza \& Metcalfe, 1997), hypoxic conditions (Foss \& Imsland, 2002) and exposure to toxic compounds (El Ghazali et al., 2009) among others. Compensatory growth has been reported in a large range of aquatic animals, such as rainbow trout (Oncorhynchus mykiss) (Nikki et al., 2004), Atlantic salmon (Salmo salar) (Nicieza \& Metcalfe, 1997), channel catfish (Ictalarus punctatusi) (Menghe et al., 2005), Pacific halibut (Hippoglossus stenolepis) (Hurst et al., 2005) and Chinese shrimp, (Fenneropenaeus chinensis) (Wei et al., 2008).

Malecha et al. (1989) suggested the occurrence of a compensatory growth in $M$. rosenbergii when small prawns are separated from the original population or transferred to lower densities. The same authors stated that age and size of the prawn are not indicators of its growth capability inasmuch as small prawns can undergo considerable growth when size-graded from a mature population into one with other prawns of similar size. Once confirmed, this characteristic would be important to reduce costs of prawn cage culture because it could make it feasible to rear postlarvae under high densities at the nursery phase.

Thus, the objective of this study was to evaluate the occurrence of a compensatory growth response in $M$. rosenbergii after a period of growth suppression, induced by nursing postlarvae in cages at high densities, followed by a growing period under normal densities.

\section{Material and Methods}

Experiments were conducted in nursery cages and growing pens (iron frames recovered with polyethylene mesh) installed in an earthen pond $\left(2400 \mathrm{~m}^{2}\right)$ located at the Centro Experimental de Aquicultura de Pindamonhangaba, Instituto de Pesca, estado de São Paulo, Brazil. Nursery cages were fixed inside pond with iron stakes, in order to avoid the contact with pond bottom. Growing pens were partially buried in the pond bottom, keeping a thin layer (about $10 \mathrm{~cm}$ ) of soil on its bottom.

Early metamorphosed postlarvae (PL), weighing $0.006 \pm 0.003 \mathrm{~g}$, were initially acclimated in a single cage for 35 days and afterwards transferred to 16 nursery cages measuring $1 \mathrm{~m}$ (length) $\times 0.5 \mathrm{~m}$ (width) $\times 0.7 \mathrm{~m}$ (depth), at densities of 50, 400, 800 and 1,200 PL m${ }^{-2}$ (initial mean weight of $0.026 \pm 0.012 \mathrm{~g}$ ). After 60 days, prawns were removed, weighed and transferred to 16 growing pens measuring $2 \mathrm{~m}$ (length) $\times 1 \mathrm{~m}$ (width) $\times 1 \mathrm{~m}$ (depth), at a density of 12 prawns $\mathrm{m}^{-2}$, according to the following treatments: 50 PL M-2 = prawns previously stocked at $50 \mathrm{PL} \mathrm{m}{ }^{-2}$ in the nursery phase; $400 \mathrm{PL} \mathrm{M}-2=$ prawns previously stocked at $400 \mathrm{PL} \mathrm{m}^{-2} ; 800 \mathrm{PL} \mathrm{M-2} \mathrm{=} \mathrm{prawns}$ previously stocked at $800 \mathrm{PL} \mathrm{m}^{-2} ; 1200 \mathrm{PL} \mathrm{M-2}=$ prawns previously stocked at $1,200 \mathrm{PL} \mathrm{m}^{-2}$. In the growing phase, prawn initial weights were the same respective mean final weights recorded after the nursery phase for the 4 densities tested: 50 PL M-2 $=2.3 \pm 0.3 \mathrm{~g}$; 400 PL M-2 $=0.5 \pm 0.03$ g; $800 \mathrm{PL} \mathrm{M}-2=0.3 \pm 0.05 \mathrm{~g}$ and $1200 \mathrm{PL} \mathrm{M}^{-2}=0.1 \pm 0.01 \mathrm{~g}$. Commercial pellets (35\% crude protein) was supplied once a day in the afternoon, at a proportion varying from $5 \%$ of prawn biomass (nursery phase) to $3 \%$ of prawn biomass (growing phase). Every 30 days, all prawns were counted and weighed, to adjust feed management and to determine mean weight, relative growth index, biomass and survival. Relative growth rate was determined through the expression: $\mathrm{RGR}=(\mathrm{Wj}-\mathrm{Wi}) \mathrm{Wi}^{-1}$, where $\mathrm{Wj}=$ mean weight in the month $\mathrm{j} ; \mathrm{Wi}=$ mean weight in the preceding month $i$. Feed conversion efficiency (FCE) was determined through the expression: $\mathrm{FCE}=(\mathrm{Bj}-\mathrm{Bi}) \mathrm{C}^{-1}$, where $\mathrm{Bj}=$ biomass in the month $\mathrm{j} ; \mathrm{Bi}=$ biomass in the month $\mathrm{i}$ and $\mathrm{C}=$ amount of feed supplied in the considered period.

Growing pens were harvested after 244 days and all prawns were counted and weighed. Prawns were also classified according to sex and to male morphotypes $(\mathrm{BC}=$ blue claw, OC = orange claw and SM = small male) according to the procedure of Ra'anan et al. (1991). Results for mean weight, relative growth rate, biomass, survival and FCE were analyzed by one-way ANOVA. Means were compared by Tukey's test (Zar, 1999). Percent data were arcsin transformed before analysis. Normality and homogeneity of variance were assessed by using Shapiro-Wilks and Bartlett tests respectively. In all tests, means were considered different when $\mathrm{P}<0.05$.

Water quality was monitored inside and outside cages and pens. Water temperatures (maximum and minimum) were recorded daily, and dissolved oxygen and $\mathrm{pH}$ were measured twice a week, in the morning (7:00 am). A paddle wheel aerator $(0.5 \mathrm{HP})$ was positioned near cages and pens and was activated daily from 10:00 p.m. to 6:00 a.m. to assure adequate water circulation.

\section{Results and Discussion}

In the nursery phase the minimum water temperature inside cages ranged from 24.3 to $27.9^{\circ} \mathrm{C}$ (mean of $26.3 \pm 1.4^{\circ} \mathrm{C}$ ), whereas maximum water temperature varied from 25.2 to $32.5^{\circ} \mathrm{C}$ (mean of $30.9 \pm 2.5^{\circ} \mathrm{C}$ ). During the growing phase, the 
monthly mean temperature inside pens ranged from a minimum of $16.5 \pm 0.9^{\circ} \mathrm{C}$ to a maximum of $28.6 \pm 1.4^{\circ} \mathrm{C}$. In later autumn and winter months (from May to August), mean water temperatures remained below $20^{\circ} \mathrm{C}$. Dissolved oxygen ranged from 5.9 to $7.3 \mathrm{mgL}^{-1}$ (mean of $6.6 \pm 0.5 \mathrm{mgL}^{-1}$ ), and $\mathrm{pH}$ varied from 6.7 to 8.3 (mean of $7.2 \pm 0.5$ ). No major differences were registered in water quality parameters inside and outside cages or pens. All the measured variables were within the acceptable limits for freshwater prawn culture (New, 2002).

There were significant differences in mean weight, biomass and survival among prawns reared at different densities in the nursery phase (Table 1 ). Mean weight was significantly higher at a density of $50 \mathrm{PL} \mathrm{m}^{-2}$ and significantly lower at the density of $1,200 \mathrm{PL} \mathrm{m}^{-2}$ when compared to 400 and $800 \mathrm{PL} \mathrm{m}^{-2}$. Maximum biomass was reached at a density of $800 \mathrm{PL} \mathrm{m}^{-2}$ and did not differ significantly, only between densities of 50 and $1200 \mathrm{PL} \mathrm{m}^{-2}$. Survival differed significantly only between densities of 50 and $1,200 \mathrm{PL} \mathrm{m}^{-2}$.

Mean weight determined at the end of the nursery phase was similar to those observed by Marques et al. (2000), also in cages, for stocking densities of 400 and $800 \mathrm{PL} \mathrm{m}^{-2}$, but it was lower than those reported by New (2002) for conventional earthen pond nurseries at a stocking density of $200 \mathrm{PL} \mathrm{m}^{-2}$ (0.8 - $2.0 \mathrm{~g}$ after 4 to 10 weeks). A mean final weight higher than $2.0 \mathrm{~g}$ was observed in the present study only for the stocking density of $50 \mathrm{PL} \mathrm{m}^{-2}$. Meanwhile, survival was good, even at the highest density $\left(1,200 \mathrm{PL} \mathrm{m}^{-2}\right)$, showing better values than those reported by Marques et al. (2000) in cages (75.4 to $87.6 \%$ ) and that reported by New (2002) for conventional earthen pond nurseries (80 - $90 \%$ ) after 60 days of culturing. Valenti and Tidwell (2006) reported survival about $80 \%$ for nursery phase in subtropical zones. Marques et al. (2000) stated that survival of prawns cultured in cages for 60 days at densities from 100 to $800 \mathrm{PL} \mathrm{m}^{-2}$ was not affected by increasing stocking densities. In the present study, the density of 1,200 PL m${ }^{-2}$ showed a significant decrease in survival, resulting in low final biomass (56.1 g). Thus, although the principal constraint factor to rearing prawns at high densities in the nursery phase seems to be the reduction in growth, survival can also be affected when stocking density exceeds $800 \mathrm{PL} \mathrm{m}^{-2}$.
After 214 days of growing, mean weight and biomass differed significantly among prawns previously nursed at densities of 50, 800 and 1,200 PL m ${ }^{-2}$ (Table 2). Maximum and minimum values of mean weight and biomass were observed, respectively, for prawns previously nursed at 50 and 1,200 $\mathrm{PL} \mathrm{m}^{-2}$. No significant differences were noted between densities of 50 and $400 \mathrm{PL} \mathrm{m}^{-2}$, as well as among densities of 400, 800 and 1,200 PL m ${ }^{-2}$. Nevertheless, after 244 days of growing, no significant difference was noted for mean weight and biomass. Despite this, prawns previously nursed at $50 \mathrm{PL} \mathrm{m}^{-2}$ showed the best values. This indicates that in the last 30 days of growing, weight gain was greater for the prawns nursed at $1,200 \mathrm{PL} \mathrm{m}^{-2}$. In fact, prawns previously reared at density of $1200 \mathrm{PL} \mathrm{m}^{-2}$ showed values of mean weight and biomass very similar to those observed for prawns nursed at $800 \mathrm{PL} \mathrm{m} \mathrm{m}^{-2}$. Survival did not differ significantly among the treatments, after 214 and 244 days of growing.

Relative growth rate after 214 days was higher for prawns previously nursed at $1,200 \mathrm{PL} \mathrm{m}^{-2}$, which differed significantly from the other treatments. Prawns nursed at $800 \mathrm{PL} \mathrm{m}^{-2}$ differed from those nursed at $50 \mathrm{PL} \mathrm{m}^{-2}$, but not from $400 \mathrm{PL} \mathrm{m}^{-2}$. However, after 244 days, relative growth rate remains significantly higher for 1,200 PL m${ }^{-2}$, only, not differing among the other densities (Table 2). FCE was significantly better for the density of 1,200 PL m-2 after 214 and 244 days of growing. If all the growing phase was considered, FCE showed best values for densities of 1,200 and $800 \mathrm{PL} \mathrm{m}^{-2}(0.45 \pm 0.02$ and $0.34 \pm 0.11)$, being significantly higher than the density of $50 \mathrm{PL} \mathrm{m}^{-2}(0.18 \pm 0.03)$. However, the density of $1,200 \mathrm{PL} \mathrm{m}^{-2}$ differed significantly only for $400 \mathrm{PL} \mathrm{m}^{-2}(0.27 \pm 0.02)$. Overall, FCE was low probably due to the weight increase depletion in winter months.

Mean weight was significantly higher for the density of $50 \mathrm{PL} \mathrm{m}^{-2}$ until November. Growth decreased during the winter months (June to August), but recovered rapidly with water temperature increase (Figure 1 ). The experiment was finished in November, however growth curves showed an increasing tendency, which probably would reduce even more the difference between densities of 800 and $1,200 \mathrm{PL} \mathrm{m}^{-2}$, if growing phase had not been interrupted.

Table 1 - Mean final weight, biomass and survival of M. rosenbergii, nursery phase, stocking density after 60 days (mean \pm SD)

\begin{tabular}{cccc}
\hline Density $\left(\mathrm{PL} \mathrm{m}{ }^{-2}\right)$ & Mean final weight $(\mathrm{g})$ & Biomass $(\mathrm{g})$ & Survival $(\%)$ \\
\hline 50 & $2.28 \pm 0.26 \mathrm{a}$ & $52.5 \pm 7.1 \mathrm{a}$ & $96.0 \pm 5.1 \mathrm{a}$ \\
400 & $0.48 \pm 0.03 \mathrm{~b}$ & $87.9 \pm 1.8 \mathrm{~b}$ & $91.3 \pm 2.9 \mathrm{a}, \mathrm{b}$ \\
800 & $0.32 \pm 0.05 \mathrm{~b}$ & $114.2 \pm 9.7 \mathrm{c}$ & $88.1 \pm 6.2 \mathrm{a}, \mathrm{b}$ \\
1200 & $0.11 \pm 0.01 \mathrm{c}$ & $56.1 \pm 6.4 \mathrm{a}$ & $80.2 \pm 4.5 \mathrm{~b}$ \\
\hline
\end{tabular}

Different letters in the same row indicate significant differences $(\mathrm{P}<0.05)$ by Tukey test. 
Relative growth rate varied during the growing phase, being greater in May and also from September to November, immediately after winter growth depression (Figure 2). In the three last months of growing, rates differed significantly among the treatments $(\mathrm{P}<0.05)$, remaining inversely proportional to the initial size of prawns stocked. From May to August, no significant difference in weight increase was observed among the treatments.

At the end of growing phase, mean weight was lower than those reported for conventional culture in natural

Table 2 - Mean weight, relative growth rate, biomass, survival and feed conversion efficiency (FCE) of prawns previously stocked at four stocking densities in the nursery phase

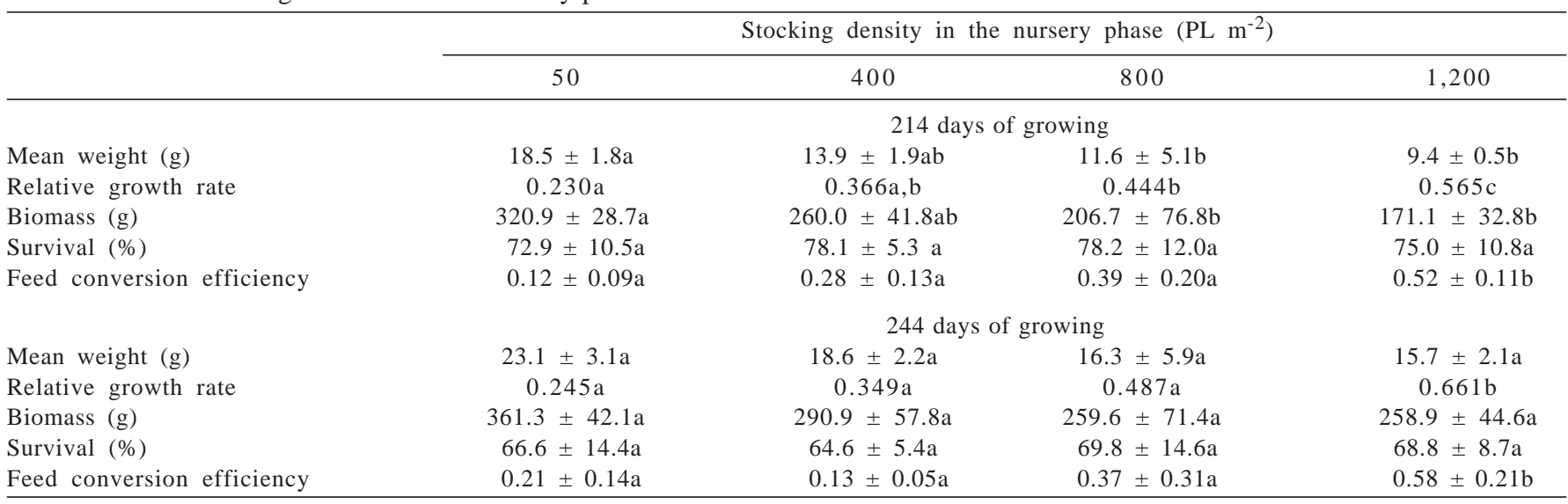

Different letters in the same row indicate significant differences $(\mathrm{P}<0.05)$ by Tukey test.

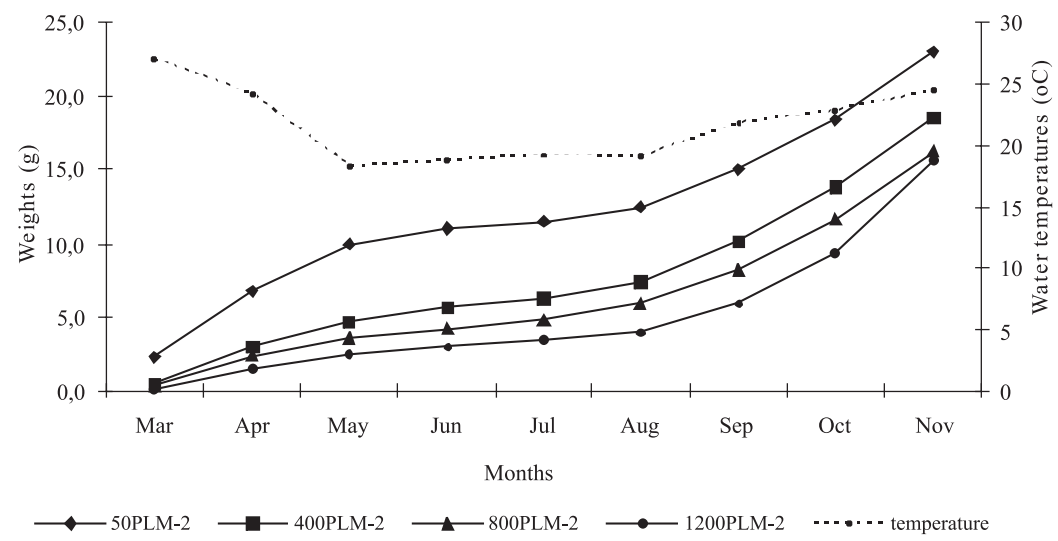

Figure 1 - Mean weights and temperatures recorded during growing phase (244 days) in pens.

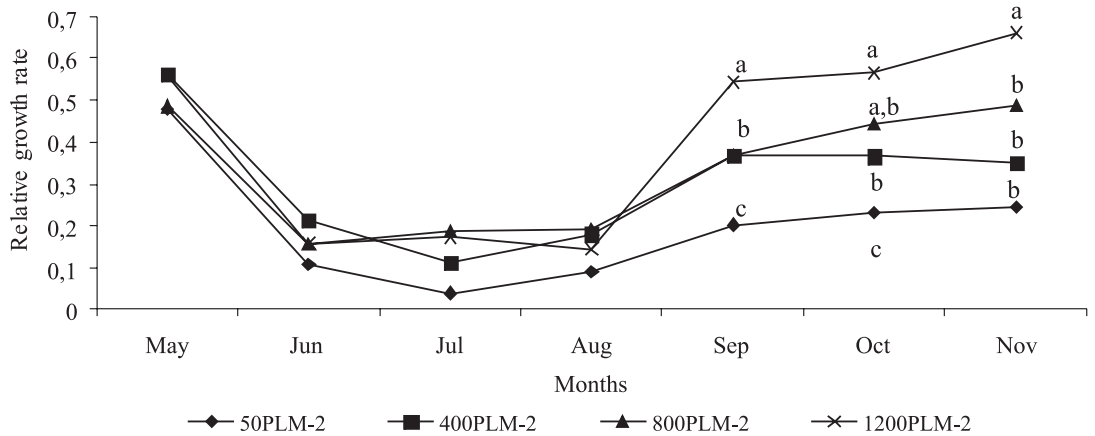

Figure 2 - Relative growth rate (weight) of $M$. rosenbergii during growing phase in pens. Different letters near the points means significant differences $(\mathrm{P}<0.05)$ according to Tukey test. 
earthen ponds in southeastern Brazil, according to the data of Marques et al. (1999), who registered mean weights of 30.0 to $34.6 \mathrm{~g}$ for prawns cultured in São Paulo State for 180 days, at a stocking density of 10 prawns $\mathrm{m}^{-2}$. New (2002) reported a mean weight of $26.0 \mathrm{~g}$ after 132 days of growing at a density of 8 prawns $\mathrm{m}^{-2}$. In the present study, prawns were stocked at higher growing density $\left(12 \mathrm{~m}^{-2}\right)$ and for longer growing period (244 days).

Survival rates observed in the present study (from 64.6 to $69.8 \%$ ) were almost similar to those mentioned by Valenti and Tidwell (2006) for semi-intensive culture in ponds (50 to $80 \%$ at the end of 4 to 6 months).

A better growth performance would be expected for prawns grown in pens rather than in cages, due to the availability of natural food on the bottom of the pen and to the presence of earth substrate. However, the results of the present study were similar to that reported by Marques et al. (1998) for growing prawns in cages (mean weight of $9.2 \mathrm{~g}$ after 90 days of culturing, at a density of 10 prawns $\mathrm{m}^{-2}$ ). Major natural feed availability in pens did not seem to have contributed to the increase in growth. Lower water temperatures in autumn and winter may have contributed to the reduction in growth, but it seems that the spatial limitation caused by the pens, as with the cages, was the main factor in restricting the growth of prawns.

No significant difference was noted in the proportion of males and females (sex-ratio) for all the treatments (Figure 3). The number of females was slightly greater in most pens, mainly at densities of 400 and $800 \mathrm{PL} \mathrm{m}^{-2}$. The proportion of male morphotypes also did not vary significantly among treatments, which were about 15\% BC, 15\% OC and 70\% SM for all groups, except for the density of $800 \mathrm{PL} \mathrm{m}^{-2}$, which showed higher proportion of OC (27\%) and lower proportion of SM (59\%) (Figure 4).

Male morphotype proportion differed from the values of $50 \%$ of small males, $40 \%$ of orange claws and $10 \%$ of blue claws proposed by Ra'Anan et al. (1991) for populations of

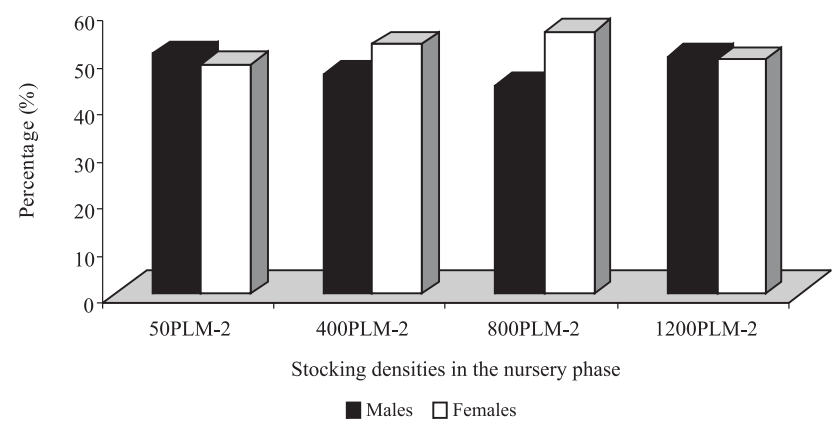

Figure 3 - Sex ratio of harvested prawns after 244 days of growing in pens.

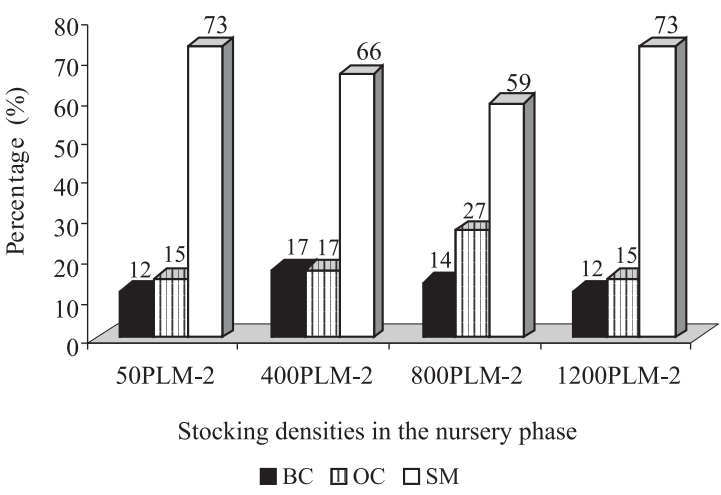

Figure 4 - Male morphotype proportion of harvested prawns after 244 days of growing in pens. BC = blue claw; $\mathrm{OC}=$ orange claw; $\mathrm{SM}=$ small male.

prawns growing in earthen ponds. In the present experiment, the proportion of OC remained below to those values, whereas the proportion of SM was very higher. This discrepancy can be attributed to the system of growing in pens which can modify the social structure of prawns due to the motility prawns restriction. The same authors above stated that at densities as low as 1 prawn $\mathrm{m}^{-2}$, the proportion of SM decreases to 33\%. Adverse effect can be expected in the pen culture, with increases in the proportion of SM. This can be a reasonable explanation for the reduced growth rate observed in cages or pens when compared to natural ponds at the same stocking density.

Many studies state that growth rate increases in fish, associated to a refeeding period, after some weeks of feed deprivation. Gaylord and Gatlin (2000) evaluated the compensatory growth in channel catfish Ictalarus punctatus starved for 4 weeks and observed that after 8 weeks of refeeding, total increase in body weight was similar to that of control group. Similar studies was conducted with rainbow trouts (Nikki et al, 2004), hybrid striped bass (Turano et al., 2007), red sea bream (Oh et al., 2007) and hybrid tilapia (Wang et al., 2000). Some authors postulated that the increase of growth rate may be a function of a hyperphagic response to the period of feed deprivation, with increases in appetite (Russel and Wootton, 1992; Nicieza and Metcalfe, 1997). Others suggest that there is a physiological mechanism that increases the energy available for growth after refeeding (Freetly et al., 1995), resulting in better feed conversion efficiency. Dobson and Holmes (1984) suggested that compensatory growth in fish could be attributed to an increased efficiency of food utilization.

The growth depression period can be induced by many factors. Hurst et al. (2005) find a growth rate $20 \%$ higher in Pacific halibuts (Hippoglossus stenolepis) previously 
reared at low temperatures $\left(2.5^{\circ} \mathrm{C}\right)$ than in fish reared continuously at $10^{\circ} \mathrm{C}$. Furthermore, growth compensating fish group were more active than the control group, thus reflecting a major foraging activity. El Ghazali et al. (2009) verified that the specific growth of zebrafish (Danio rerio) larvae pre-exposed to a toxic bloom extract of Microcystis aeruginosa were significantly higher than that of control group. Wei et al. (2008) studied the growth in juveniles of Fenneropenaeus chinensis prawns previously exposed to hypoxic water for 10 days and then transferred to normoxic water. The juveniles completely compensated the growth depression in 30 days after transference and the compensation was achieved mainly by hyperphagia and improvement in feed conversion efficiency.

El Ghazali et al. (2009) stated that to obtain a compensatory growth, two phases are needed: a first phase of stress during which the growth of the animals is reduced, followed immediately by the second phase during which the growth depressor disappears, which allows the resumption of the growth but at a rate below the physiological potential of the animal (compensatory growth). Ali et al. (2003) stated that partial, full and over-compensation have all been evoked in fish and Nicieza and Metcalfe (1997) found that compensatory growth continued after the deprived fish had attained the same length/mass relationship as the control group. At the present study, full compensation was only achieved for prawns previously nursed at 1,200 $\mathrm{PL} \mathrm{m}^{-2}$ when compared to those nursed at $800 \mathrm{PL} \mathrm{m}{ }^{-2}$.

The significant differences in mean weight and biomass observed among the treatments after 214 days and the non-significant differences registered after 244 days of growing, as well as the higher relative growth rate and better feed efficiency recorded for prawns previously nursed at 1,200 $\mathrm{PL} \mathrm{m}{ }^{-2}$, suggest the occurrence of compensatory growth in these prawns, although it was not as evident as suggested by Malecha et al. (1989). On the other hand, the low growth rate recorded in pens, as well as the decrease in temperature during winter could have delayed the perception of compensatory growth, which was more evident after prawns had reached a weight of about $10 \mathrm{~g}$.

Increases in feed conversion efficiency have been reported in several species, achieving compensatory growth (Wei et al., 2008; Oh et al., 2007). Gaylord and Gatlin (2000) showed that increase in feed efficiency was transient, lasting only the first 2 weeks of refeeding. Hyperphagia is also considered an important mechanism leading to compensatory growth of species during the refeeding period (Oh et al., 2007). In the present study, hyperphagia behavior could not be observed inasmuch as feed was not offered "ad libitum”, but feed efficiency was associated to a major relative growth rate in prawns nursed in the high density, and remained significantly higher until the end of the experiment.

Compensatory growth at the present study may has been influenced by the size grading of juveniles before the stocking in pens. This grading has not been done only for the prawns nursed at the density of $50 \mathrm{PL} \mathrm{m}^{-2}$. Tidwell et al. (2005) states that size grading avoid the continuation of the socially induced differential growth rates, leading to an increase in population growth and improving feed conversion. However, in this experiment, juveniles were equally size graded for the densities of 400,800 and $1,200 \mathrm{PL} \mathrm{m}^{-2}$. Thus the influence of grading within these treatments was minimized.

Malecha et al. (1989) stated that rearing prawns at high densities (about $1000 \mathrm{PL} \mathrm{m}^{-2}$ ) during the nursery phase, before transference to growing ponds, could be a good strategy to reduce costs, due to the optimization of available space. The findings of the present study suggest that growing prawns in cages or pens, after previous stocking at high densities, is not recommended inasmuch as it results in low growth rates, even at normal growing densities, despite of good survival. Otherwise, these results allow proposing that nursing $M$. rosenbergii in cages or pens at densities of about $800 \mathrm{PL} \mathrm{m}^{-2}$ with subsequent transference to growing natural earthen ponds may be feasible because the growth restriction observed at a previous high stocking density can be compensated after the transference to conventional densities.

The results of this experiment should be carefully interpreted because the low temperatures registered affected negatively the performance of prawns. It would be interesting to carry out a new experiment under more favorable temperatures, when a different response in terms of compensatory growth would likely to be obtained, as found by Wu et al. (2002). Likewise, an experiment conducted in natural ponds instead of cages might present different results than those observed in this study and it should be considered in a forthcoming research

\section{Conclusions}

The results from the present study demonstrate the occurrence of partial compensatory growth in M. rosenbergii previously nursed at high densities. Prawns previously stocked at 1,200 juveniles $\mathrm{m}^{-2}$ show more visible compensatory growth when compared with prawns stocked at $800 \mathrm{~m}^{-2}$. However, due to the better survival, stocking densities about $800 \mathrm{PL} \mathrm{m}^{-2}$ in the nursery phase seem to be recommended for culture purposes. 


\section{Aknowledgements}

The authors are grateful to FAPESP - São Paulo State Research Support Foundation for partially funding this research (Pr. 03-07983-3).

\section{References}

ALI, M.; NICIEZA, A.; WOOTTON, R.J. Compensatory growth in fishes: a response to growth depression. Fish and Fisheries, v.4, n.2, p.147-190, 2003.

DOBSON, S.H.; HOLMES, R.M. Compensatory growth in the rainbow trout, Salmo gairdneri Richardson. Journal of Fish Biology, v.25, n.6, p.649-656, 1984.

EL GHAZALI, I.; SAQRANE, S.; CARVALHO, A.P. et al. Compensatory growth induced in zebrafish larvae after preexposure to a Microcystis aeruginosa natural bloom extract containing microcystins. International Journal of Molecular Sciences, v.10, n.1, p.133-146, 2009.

FOOD AND AGRICULTURE ORGANIZATION OF THE UNITED NATIONS - FAO. Yearbook of fishery statistics: summary tables. Available in: <http://www.fao.org. $>$. Access in: 4/8/2009.

FOSS, A.; IMSLAND, A.K. Compensatory growth in the spotted wolffish Anarrhichas minor (Olafsen) after a period of limited oxygen supply. Aquaculture Research, v.33, n.13, p.1097-1101, 2002 .

FREETLY, H.C.; FERRELL, C.L.; JENKINS, T.G. et al. Visceral oxygen consumption during chronic feed restriction and realimentation in sheep. Journal of Animal Science, v.73, n.3, p.843-852, 1995.

GAYLORD, T.G.; GATLIN III, D.M. Assessment of compensatory growth in channel catfish Ictalurus punctatus R. and associated changes in body condition indices. Journal of the World Aquaculture Society, v.31, n.3, p.326-336, 2000.

HURST, T.P.; SPENCER, M.L.; SOGARD, S.M. et al. Compensatory growth, energy storage and behavior of juvenile Pacific halibut Hippoglossus stenolepis following thermally induced growth reduction. Marine Ecology Progress Series, v.293, n.2, p.233-240, 2005.

MALECHA, S.R.; SANDIFER, P.A.; COTSAPAS, L. et al. Potential application to Brazil of recent advances in the culture of marine shrimps and freshwater prawns. In: BRAZILIAN SYMPOSIUM ON PRAWN CULTURE, 3., 1989, João Pessoa. Anais... João Pessoa, Associação Brasileira de Criadores de Camarão, 1989. p.33-47.

MARQUES, H.L.A.; LOMBARDI, J.V.; CAMPOS, A.F. et al. Viability of culturing freshwater prawns Macrobrachium rosenbergii in cage systems, in Brazil. AQÜICULTURA BRASIL'98, 1998, Recife. Anais... Recife: Associação Brasileira de Aqüicultura, 1998. p.383-389.

MARQUES, H.L.A.; LOMBARDI, J.V.; LOBÃO, V.L. et al. Efeito de dois tipos de manejo alimentar sobre o crescimento do camarão de água doce (Macrobrachium rosenbergii de Man) cultivado em viveiros. Revista Ceres, v.46, n.1, p.19-27, 1999.
MARQUES, H.L.A.; LOMBARDI, J.V.; BOOCK, M.V. Stocking densities for nursery phase culture of the freshwater prawn Macrobrachium rosenbergii in cages. Aquaculture, v.187, n.1-2, p.127-132, 2000.

MENGHE, H.L.; ROBINSON, E.H.; BOSWORTH, B.G. Effects of periodic feed deprivation on growth, feed efficiency, processing yield and body composition of channel fish Ictalurus punctatus. Journal of the World Aquaculture Society, v.36, n.4, p.444-453, 2005.

NEW, M.B. Farming freshwater prawns: a manual for the culture of the giant river prawn (Macrobrachium rosenbergii). FAO Fish Technical Paper, n.428, p.212, 2002.

NICIEZA, A.G.; METCALFE, N.B. Growth compensation in juvenile Atlantic salmon: responses to depressed temperature and food availability. Ecology, v.78, n.8, p.2385-2400, 1997.

NIKKI, J.; PIRHONEN, J.; JOBLING, M. et al. Compensatory growth in juvenile rainbow trout, Oncorhynchus mykiss (Walbaum), held individually. Aquaculture, v.235, n.1-4, p.285-296, 2004.

OH, S.Y.; NOH, C.H.; CHO, S.H. Effect of restricted feeding regimes on compensatory growth and body composition of Red Sea bream Pagrus major. Journal of the World Aquaculture Society, v.38, n.3, p.443-449, 2007.

RA'ANAN, Z.; SAGI, A.; WAX, I. et al. Growth, size rank and maturation of the freshwater prawn, Macrobrachium rosenbergii: analysis of marked prawns in a experimental population. Biological Bulletin, v.181, n.3, p.379-386, 1991.

RUSSELL, N.R.; WOOTTON, R.J. Appetite and growth compensation in the European minnow, Phoxinus phoxinus (Cyprinidae) following short term of food restriction. Environmental Biology of Fishes, v.34, n.3, p.277-285, 1992.

TIDWELL, J.H.; D'ABRAMO, L.R.; COYLE, S.D. et al. Overview of recent research and development in temperate culture of the freshwater prawn (Macrobrachium rosenbergii De Man) in the South Central United States. Aquaculture Research, v.36, n.3, p.264-277, 2005.

TURANO, M.J.; BORSKI, R.J.; DANIELS, H.V. Compensatory growth of pond-reared hybrid striped bass Morone chrysops X Morone saxatilis, fingerlings. Journal of the World Aquaculture Society, v.38, n.2, p.250-261, 2007.

VALENTI, W.C.; TIDWELL, J.H. Economics and management of freshwater prawn culture in Western Hemisphere. In: LEUNG, P.S.; ENGLE, C. (Eds.) Shrimp culture: economics, market and trade. Oxford: Blackwell, 2006. p.263-278.

WANG, Y.; CUI, Y.; YANG, Y. et al. Compensatory growth in hybrid tilapia Oreochromis mossambicus x Oreochromis niloticus reared in sea water. Aquaculture, v.189, n.1-2, p.101-108, 2000.

WEI, L.Z.; ZHANG, X.M.; LI, J. et al. Compensatory growth of Chinese shrimp, Fenneropenaeus chinensis following hypoxic exposure. Aquaculture International, v.16, n.6, p.455-470, 2008.

WO, L.; DONG, S. Compensatory growth responses in juvenile Chinese shrimp, Fenneropenaeus chinensis, at different temperatures. Journal of Crustacean Biology, v.22, n.3, p.511-520, 2002.

ZAR, J.H. Biostatistical analysis. 4.ed. Upper Saddle River: Prentice Hall, 1999. 929p. 